\title{
Antibodies against p53 protein in serum of patients with benign or malignant pancreatic and biliary diseases
} P Laurent-Puig, R Lubin, S Semhoun-Ducloux, G Pelletier, C Fourre, M Ducreux,
M J Briantais, C Buffet, T Soussi

\begin{abstract}
Specific markers for pancreatic or biliary cancer have been developed in the past few years. Ca 19-9 has a good sensitivity but it is also increased in benign cholestasis. Mutations in the p53 gene are commonly reported in pancreatic cancer and can be detected by a serological analysis. The aim of this work was to find out the sensitivity and specificity of this new assay in diagnosing cancer of the pancreas or of the bile ducts. The presence of antibodies against p53 was determined by an enzyme linked immunosorbent assay (ELISA) in 29 patients with pancreatic cancer, 33 with biliary tract cancer, and 33 with benign biliary or pancreatic diseases as controls. p53 Antibodies were detected in eight of 29 patients with pancreatic cancer $(28 \%)$, in five of 33 patients with biliary tract $(15 \%)$, and in one patient $(3 \%)$ with stones of the common bile duct. The sensitivity and the specificity for the diagnosis of malignant biliary or pancreatic diseases were $21 \%$ and $96 \%$ respectively. It is concluded that the presence of $p 53$ antibodies in the serum of patients with pancreatic and biliary diseases is specific for malignancy and independent from the presence of cholestatic disease.

(Gut 1995; 36: 455-458)
\end{abstract}

Keywords: pancreatic disease, biliary disease, p53 protein.

Service des Maladies du Foie et de l'Appareil Digestif

P Laurent-Puig

S Semhoun-Ducloux

G Pelletier

$M$ Ducreux

M J Briantais

C Buffet

and Service de

Biophysique, Hôpital

de Bicêtre, Le

Kremlin-Bicêtre,

France

C Fourre

Unité U301 INSERM, Paris, France

R Lubin

T Soussi

Correspondence to:

Dr P Laurent-Puig, Service des Maladies du Foie et de l'Appareil Digestif, Hôpital de Bicêtre, 78 Avenue du Général-Leclerc, $94275 \mathrm{~L}$ Kremlin-Bicêtre, France.

Accepted for publication 24 June 1994 sensitivity, specificity, and predictive valu the diagnosis of pancreatic cancer, 24 the justified.

TP53 is a tumour suppressor gene located on the short arm of chromosome 17. It encodes a $53 \mathrm{kD}$ nuclear phosphoprotein with probable cell cycle regulatory function and a putative transcriptional activity. ${ }^{5-7}$

Mutations in the p53 gene are the most commonly reported somatic gene changes in human cancer. ${ }^{89}$ Taking into account the 10 most common malignant tumours worldwide, p53 changes seem to be present in 40 to $45 \%$ of all tumours. They have been found in a wide variety of human malignancies including cancers of the lung, ${ }^{10-13}$ colon, ${ }^{1415}$ breast, ${ }^{16-18}$ oesophagus, ${ }^{19}$ skin, ${ }^{20}$ and pancreas. ${ }^{21-25}$

TP53 gene mutation results in the synthesis of a mutant protein, which has a much longer half life than that of the wild type protein and accumulates in transformed cells. This finding encourages an extensive study of the expression of p53 protein by immunohistochemistry in a large panel of tumours. In addition a good correlation between p53 gene mutation and protein accumulation has been found. Increased expression of p53 has been shown immunohistochemically in frozen and paraffin wax embedded sections of a wide variety of tumours including colon, ${ }^{26-29}$ ovarian, ${ }^{30}$ lung, 3132 and breast cancers. ${ }^{33} 34$

In addition to the molecular and immunohistochemical analysis, a serological analysis can be performed to identify p53 changes. Antibodies against p53 protein have been detected in the serum of patients with breast carcinoma, ${ }^{35-38}$ Burkitt's lymphoma, ${ }^{35}$ colorectal cancer, ${ }^{39}$ and lung carcinoma. ${ }^{40}$ Several studies have shown that those antibodies are usually associated with the presence of a mutant p53 protein accumulated in tumour cells. Furthermore, recent data suggest that this antibody response might be the result of a self immunisation process as the pattern of the immune response of patients with p53 antibodies is similar to those of animals hyperimmunised with wild type p53. ${ }^{41}$

In pancreatic cancer the prevalence of p53 mutations is higher and could be estimated to $40 \%-60 \%$ either directly by identification of the mutation or indirectly by immunochemistry. ${ }^{21-25}$

With this background, we decided to look for antibodies in serum from patients with either pancreatic or biliary cancer. The purpose of this investigation was to determine the sensitivity and specificity of this new assay in diagnosing cancer of the pancreas or of the bile ducts and to compare this new assay with the more conventional CA 19.9 and CEA assays. A control group, which represented the serum samples of patients with benign 
disorders who presented with signs and symptoms that might mimic those of pancreatic cancer or bile duct carcinoma was used so that the diagnostic value of this test could be measured.

\section{Methods}

\section{PATIENT GROUP}

Twenty nine serum samples of patients with pancreatic cancer and 33 serum samples of patients with biliary tract cancer were tested. In each group of tumours, two patients had a resectable disease. The other patients had disseminated tumours. The serum samples were collected at admission. A tissue diagnosis was obtained in 10 of 29 patients with pancreatic cancer and 12 of 34 patients with biliary tract cancer. The histological diagnosis in patients with biliary tract neoplasms was ampullary cancer in five cases and common bile duct carcinoma in the remaining seven cases. All histologically confirmed pancreatic cancer were adenocarcinoma. Pancreatic cancers were limited to pancreatic glands in three cases; eight were metastatic at the time of diagnosis and the remaining 18 were extended to the duodenum, common bile duct or stomach without evidence of metastatic disease. Serum samples of patients with tumours that did not have a confirmed histological diagnosis were included in this study on the basis of at least three of the following examinations: endoscopic ultrasonography, tomodensitometry, endoscopic retrograde cholangiopancreatography (ERCP), or abdominal angiography. Each medical record was evaluated blindly by two senior members of staff. Only serum of patients with concordant diagnosis of pancreatic or biliary tract neoplasm were finally included.

CONTROL GROUPS

We also tested serum samples from 33 patients with benign biliary or pancreatic diseases. Eleven had chronic pancreatitis and 22 choledocolithiasis. The diagnosis of chronic pancreatitis was based on the presence of pancreatic calcification or pattern of the Wirsung duct at ERCP. Serum samples were collected before treatment. The presence or absence of jaundice at the time of serum sampling was determined for each patient and the bilirubin concentration was recorded.

\section{ELISA TEST}

The presence of antibodies against p53 was determined by ELISA as described elsewhere. ${ }^{42}$ Briefly, we have devised a highly specific ELISA by testing all samples with a two antigen preparation. The first preparation contained the relevant antigen (p53 protein) whereas in the second preparation the antigen was omitted. All the results have been expressed as the ratio between the value of the wells with p53 antigen and the corresponding wells without. Studies on samples from healthy blood donors (200) and patients with various carcinomas (more than 1000) showed that a ratio higher than two confirms the presence of p53 antibodies. Positive samples were confirmed by a second ELISA using p53 immunodominant peptide as antigen. ${ }^{41}$ The other tumour markers were tested with commercially available radioimmunoassay kits. Cut off concentrations of $37 \mathrm{U} / \mathrm{ml}$ for CA 19.9 (Cis-Oris, Saclay, France) and $5 \mu \mathrm{g} / \mathrm{l}$ for CEA (Berhing Werke, Marburg, Germany) were recommended by the manufacturers.

\section{STATISTICAL METHODS}

Bilirubin, CEA, and CA 19.9 concentrations were compared by Student's $t$ test. A stepwise logistic regression was used to analyse the contribution of each patient's tumour markers to a classification in two groups: malignant or benign diseases. The continuous variables CA 19.9 and CEA were transformed to categories taking into account the cut off value for each variable.

\section{Results}

p53 Antibodies were detected in eight of 29 patients with pancreatic cancer $(28 \%)$, in five of 33 with biliary tract cancer $(15 \%)$, and in one patient $(3 \%)$ with stones of the common bile duct. None of those with chronic pancreatitis were positive.

Patients with pancreatic cancer or bile duct neoplasm were classified in two groups according to the absence (group 1) or presence (group 2) of p53 antibodies in their serum. Table I gives the mean and the standard deviation of age, bilirubin, CA 19.9, and CEA for each group. The only statistically significant difference between the two groups was that patients with antibodies against p53 were younger than patients without. No correlation was seen between the degree of invasiveness of the tumour and the prevalence of antibodies against p53 in the serum of patients. Indeed, none of the patients with pancreatic cancers that were limited to pancreatic glands had antibodies against $\mathrm{p} 53$ protein detectable in their serum, and only one patient with metastatic disease had p53 antibodies in his serum.

Results from patients with pancreatic cancer or with biliary tract cancer were grouped together, as well as the results from the group of patients with chronic pancreatitis or with choledocolithiasis diseases. Table II gives the sensitivity and the specificity values and the predictive positive and negative values of each maker tested in this series for distinguishing

TABLE I Patient groups

\begin{tabular}{lccl}
\hline & $\begin{array}{l}\text { Group 1 } \\
(n=50) \\
p 53 \text { negative }\end{array}$ & $\begin{array}{l}\text { Group 2 } \\
(n=13) \\
p 53 \text { positive }\end{array}$ & \\
\hline Age & $74(14)$ & $64(11)$ & $\mathrm{p}<0.02$ \\
Bilirubin $(\mu \mathrm{mol} / \mathrm{l})$ & $167(159)$ & $244(156)$ & $\mathrm{NS}$ \\
CEA $(\mu \mathrm{g} / \mathrm{l})$ & $22(43)$ & $33(88)$ & $\mathrm{NS}$ \\
CA $19 / 9(\mathrm{U} / \mathrm{ml})$ & $5643(11982)$ & $13222(19274)$ & $\mathrm{NS}$ \\
\hline
\end{tabular}

Group 1: patients with cancer and no antibodies against p53 in their serum. Group 2: patients with cancer and antibodies against p53 in their serum. Data expressed as mean (SD). 
TABLE II Sensitivity, specificity values, predictive positive and negative values of each marker for distinguishing between malignant and benign pancreatic or biliary diseases

\begin{tabular}{lllll}
\hline & $\begin{array}{l}\text { Sensitivity } \\
(\%)\end{array}$ & $\begin{array}{l}\text { Specificity } \\
(\%)\end{array}$ & $\begin{array}{l}P P V^{\star} \\
(\%)\end{array}$ & PNVt \\
\hline CEA & 60 & 72 & 80 & 49 \\
CA 19.9 & 96 & 52 & 79 & 89 \\
p53 & 21 & 96 & 92 & 39 \\
\hline
\end{tabular}

$\star P P V=$ predictive positive value $+\mathrm{PNV}=$ predictive negative value. The cut off value was $37 \mathrm{U} / \mathrm{ml}$ and $5 \mu \mathrm{g} / \mathrm{l}$ for $\mathrm{CA} 19.9$ value. The cut off value

between malignant and benign diseases. Serum concentrations of CA 19.9 and CEA and presence or absence of serum p53 antibodies were selected as independent variables in a stepwise regression (significance value for entry into the model $=0 \cdot 10$ ), with malignant or benign disease as a dependent variable. The three variables were estimated to be independently predictive of malignant diseases (Table III). Two types of combinations were tested according to the presence of both high CA 19.9 concentrations and p53 antibodies, or only one of these markers. Table IV shows the results. They show no significant improvement in diagnostic ability.

\section{Discussion}

The prevalence of antibodies against p53 protein in serum of patients with pancreatic cancer reported here $(29 \%)$ is higher than those described previously. Indeed, the serum prevalence of $\mathrm{p} 53$ antibodies range from 9\% to $14 \%$ in breast cancer, ${ }^{35-38} 10 \%$ in lung cancer, ${ }^{40} 12.5 \%$ in colorectal cancer, ${ }^{39}$ and $20 \%$ in lymphoma B. ${ }^{35}$ It should be noted that the prevalence of p53 antibodies in serum samples from patients with pancreatic cancer is almost twofold that seen in serum samples from patients with colorectal cancer, although the prevalence of p53 gene mutation in colorectal cancer and in pancreatic cancer are very similar. A possible explanation for this finding could be that in our series most of our patients had unresectable pancreatic cancer and therefore an advanced disease. We cannot exclude the possibility, however, that the difference may result from the procedures used for detection of p53 antibodies. The western blot assay used in previous studies is far less sensitive than the ELISA described here. Finally, the possibility of other variations caused by sampling or bias in patient selection remains.

Among the serum samples positive for p53 antibodies, one was detected in a patient with stones of the common bile duct. This result is unexpected because it is generally assumed

TABLE III Summary of stepwise results

\begin{tabular}{llllll}
\hline Step & Variable & Categories & $p$ Value & $R R$ & $95 \%$ CI \\
\hline 1 & CA 19.9 & $\leqslant 37$ & $<0.000$ & 34.2 & 5.96 to 196 \\
2 & CEA & $>37$ & & & \\
3 & Serum anti-p53 & $\begin{array}{c}\text { Absence } \\
\text { Presence }\end{array}$ & $<0.024$ & 3.57 & 1.11 to 11.5 \\
& & & $<0.072$ & 6.21 & 0.567 to 68
\end{tabular}

$\mathrm{CI}=$ confidence intervals; $\mathrm{RR}=$ relative risk of malignant pancreatic or biliary disease in a logistic regression model using forward stepwise procedure. Significance value for entry into the model $=0 \cdot 10$.
TABLE IV Sensitivity and specificity values, predictive positive and negative values of combinations of markers (CA 19.9 or $p 53$, or both) for the differentiation between malignant and benign pancreatic or biliary diseases

\begin{tabular}{lllll}
\hline & $\begin{array}{l}\text { Sensitivity } \\
(\%)\end{array}$ & $\begin{array}{l}\text { Specificity } \\
(\%)\end{array}$ & $\begin{array}{l}\text { PPV } \\
(\%)\end{array}$ & $\begin{array}{l}\text { PNV } \\
(\%)\end{array}$ \\
\hline $\begin{array}{l}\text { CA 19.9+ and p53+ } \\
\text { CA 19.9+ or p53+, } \\
\text { or both }\end{array}$ & 18 & 97 & 93 & 39 \\
\hline
\end{tabular}

The cut off value was $37 \mathrm{U} / \mathrm{ml}$ for CA 19.9. Abbreviations as in Table II.

that p53 antibodies are correlated with a p53 protein overexpression in tumoral cells. One hypothesis to explain this finding is the presence of an occult cancer that has yet to be detected. In fact, p53 antibodies have been detected in a man six months before the diagnosis of a lung cancer, ${ }^{42}$ suggesting that p53 antibodies are present very early in the cancer progress. In this work, p53 antibodies were always found at the time of diagnosis. The finding of p53 antibodies in patients with non-malignant diseases raises the possibility that it could be a very early marker. This is currently under investigation.

The number of patients with pancreatic tumour is tool small to show any evidence of correlation between the stage of the disease and the presence or absence of p53 antibodies. Only two divergent findings were noticed: (a) one patient with metastatic disease had p53 antibodies in his serum sample, (b) none of the patients with local disease had p53 antibodies. In ampullary cancer or cholangiocarcinoma, no data are available on the frequency of p53 gene mutation. It can be assumed to be comparable with that seen in breast carcinoma with regard to the frequency of p53 antibodies found in this study.

A CA 19.9 serum concentration above $37 \mathrm{U} / \mathrm{ml}$ (the reference value between positive and negative scores) was frequently seen in obstructive jaundice, even in patients with benign biliary tract disease. ${ }^{3}$ CA 19.9 is therefore not a valuable tumour marker in the diagnosis of cephalic pancreatic cancer. In contrast, the presence of p53 antibodies in the serum seemed to be independent from the presence of a cholestatic disease, and seemed very specific for malignant pancreatic or biliary diseases. But the low sensitivity of such a test reduces its clinical interest. Given the high specificity of the assay, however, would be a valuable contribution to diagnosis and could be used as a confirmation test.

1 Safi F, Berger HG, Bittner R, Büchler M, Krautzberger W. CA $19-9$ and pancreatic adenocarcinoma. Cancer 1985; 57: 779-83.

2 Röthlin MA, Joller H, Largiader F. CA 242 is a new tumour marker for pancreatic cancer. Cancer 1992; 71: 701-7.

3 Benamouzig R, Buffet C, Fourre C, Ink O, Moatti F, Etienne JP. Serum level of carbohydrate antigenic determinant (CA 19-9) in obstructive jaundice. Dig Dis Sci 1989; 34: 1640-2.

4 Paganuzzi $M$, Onetto $M$, Marroni $P$, Barone $D$, Conio $M$, Aste $\mathrm{H}$, et al. CA $19-9$ and CA 50 in benign and malignant pancreatic and biliary diseases. Cancer 1987; 61: 2100-8. Levine AJ, Momand J, Finlay CA. The p53 tumour suppressor gene. Nature 1991; 351: 453-6.

6 Lane DP, Benchimol S. p53: oncogene or anti-oncogene? Gene Dev 1990; 4: 1-8. 7 Vogelstein B, Kinzler KW. p53 function and dysfunction. 
8 Caron de Fromentel C, Soussi T. TP53 Tumour suppressor gene: a model for investigating human mutagenesis. Genes Chromoson Cancer 1992; 4: 1-15.

9 Hollstein M, Sidransky D, Vogelstein B, Harris CC. p53 mutations in human cancers. Science 1991; 253: 49-53.

10 Mitsudomi T, Steinberg SM, Nau MM, Carbone D, Damico D, Bodner S, et al. p53 gene mutations in nonsmall-cell lung cancer cell lines and their correlation with the presence of ras mutations and clinical features. Oncogene 1992; 7: 171-80.

11 D'Amico D, Carbone D, Mitsudomi T, Nau M, Fedorko J, Russell $\mathrm{E}$, et al. High frequency of somatically acquired p 53 mutations in small-cell lung cancer cell lines and p53 mutations in small-cell lung canc

12 Takahashi T, Nau MM, Chiba I, Birrer MJ, Rosenberg RK, Vinocour M, et al. p53 - a frequent target for genetic abnormalities in lung cancer. Science 1989; 246: 491-4.

13 Chiba I, Takahashi T, Nau MM, d'Amico D, Curiel DT, Mitsudomi $\mathrm{T}$, et al. Mutations in the p53 gene are frequent in primary, resected non-small-cell lung cancer. Oncogene 1990; 5: 1603-10.

14 Baker SJ, Preisinger AC, Jessup JM, Paraskeva C, Markowitz S, Willson JKV, et al. p53 gene mutation occur in combination with $17 \mathrm{p}$ allelic deletions as late events in colorectal tumourigenesis. Cancer Res 1990; 50: 7717-22.

15 Hamelin R, Jego N, Laurent-Puig P, Vidaud M, Thomas G. Efficient screening of $\mathrm{p} 53$ mutations by denaturing Efficient screening of p53 mutations by denaturing Oradient gel electrophoresi

16 Prosser J, Thompson AL, Cranston G, Evans HJ. Evidence that $\mathrm{p} 53$ behaves as a tumour suppressor gene in sporadic breast tumours. Oncogene 1990; 5: 1573-9.

17 Varley JM, Brammar WJ, Lane DP, Swallow JE, Dolan C Walker RA. Loss of chromosome-17p13 sequences and mutation of p53 in human breast carcinomas. Oncogen 1991; 6: 413-21.

18 Coles C, Condie A, Chetty U, Steel CM, Evans HJ, Prosser J. p53 mutations in breast cancer. Cancer Res 1992; 52: 5291-8.

19 Hollstein MC, Metcalf RA, Welsh JA, Montesano R, Harris CC. Frequent mutation of the p53 gene in human esophageal

20 Brash DE, Rudolph JA, Simon JA, Lin A, Mckenna GJ Baden HP, et al. A role for sunlight in skin cancer - UV in squamous cell carcinoma. Proc Natl Acad Sci USA 1991; 88: 10124-8.

21 Kalthoff H, Schmiegel W, Roeder C, Kasche D, Schmidt A, Lauer G, et al. p53 and K-ras alterations in pancreatic epithelial cell lesions. Oncogene 1993; 8: 289-98.

22 Barton CM, Staddon SL, Hughes CM, Hall PA, O'Sullivan $\mathrm{C}$, Kloppel G, et al. Abnormalities of the p53 turmour , 1991; 64: 1076-82.

23 Ruggeri B, Zhang SY, Caamano J, Dirado M, Flynn SD, Kleinszanto AJP. Human pancreatic carcinomas and cel lines reveal frequent and multiple alterations in the p53 and Rb-1 tumour-suppressor genes. Oncogene 1992; 7 1503-11.

24 Scarpa A, Capelli P, Mukai K, Zamboni G, Oda T, Iacono C, et al. Pancreatic adenocarcinomas frequently show p 53 gene mutations. Am f Pathol 1993; 142: 1534-43.

25 Casey G, Yamanaka Y, Fries H, Kobrin MS, Lopez ME Buchler $\mathrm{M}$, et al. p53 mutations are common in pancreatic cancer and are absent in chronic pancreatitis. Cancer Lett 1993; 69: 151-60.

26 Van der Berg FM, Tigges AJ, Schipper MEI, Den HarogJager FCA, Kroes WGM, Walboomers JMM. Expression of the nuclear oncogene p53 in colon tumours. $\mathcal{F}$ Pathol 1989; 157: 193-9.

27 Scott N, Sagar P, Stewart J, Blair GE, Dixon MF, Quirke P. p53 in colorectal cancer - clinicopathological correlation and prognostic significance. Br f Cancer 1991; 63: 317-9.

28 Purdie CA, Ogrady J, Piris J, Wyllie AH, Bird CC. p53 expression in colorectal tumours. Am $\mathcal{F}$ Pathol 1991; 138: 807-13.

29 Campo E, Delacellemartin O, Miquel R, Palacin A Romero M, Fabregat V, et al. Loss of heterozygosity of 53-gene and p53-protein expression in human colorectal carcinomas. Cancer Res 1991; 51: 4436-42.

30 Marks JR, Davidoff AM, Kerns BJ, Humphrey PA, Pence JC, Dodge RK, et al. Overexpression and mutation of p53 in epithelial ovarian cancer. Cancer Res 1991; 51: 2979-84.

31 Caamano J, Ruggeri B, Momiki S, Sickler A, Zhang SY, Kleinszanto AJP. Detection of p53 in primary lung tumours and nonsmall cell lung carcinoma cell lines. Am f Pathol 1991; 139: 839-45.

32 Iggo R, Gatter K, Bartek J, Lane D, Harris AL. Increased expression of mutant forms of $\mathrm{p} 53$ oncogene in primary lung cancer. Lancet 1990; 335: 675-9.

33 Cattoretti G, Rilke F, Andrealo S, D'amato L, Delia D. p53 expression in breast cancer. Int $\mathcal{f}$ Cancer 1988; 41 expression

34 Bartek J, Iggo R, Gannon J, Lane DP. Genetic and immunochemical analysis of mutant p53 in human breast cancer cell lines. Oncogene 1990; 5: 893-9.

35 Caron de Fromentel C, May-Levin F, Mouriesse H, Lemerle J, Chandrasekaran K, May P. Presence of circulating antibodies against cellular protein $\mathrm{p} 53$ in a notable proportion of children with B-cell lymphoma. Int $f$ Cancer 1987; 39: 185-9.

36 Crawford LV, Pim DC, Bulbrook RD. Detection of antibodies against the cellular protein $\mathrm{p} 53$ in sera from patients with breast cancer. Int $\mathcal{F}$ Cancer 1982; 30: 403-8.

37 Davidoff AM, Iglehart JD, Marks JR. Immune response to 553 is dependent upon $53 / \mathrm{HSP} 70$ complexes in breast cancers. Proc Natl Acad Sci USA 1992; 89: 3439-42.

38 Schlichtholz B, Legros Y, Gillet D, Gaillard C, Marty M, Lane $\mathrm{D}$, et al. The immune response to $\mathrm{p} 53$ in breas cancer patients is directed against immunodominan epitopes unrelated to the mutational hot spot. Cancer Res 1992; 52: 6380-4.

39 Crawford LV, Pim DC, Lamb P. The cellular protein p53 in human tumours. Mol Biol Med 1984; 2: 261-72.

40 Winter SF, Minna JD, Johnson BE, Takahashi T, Gazdar AF, Carbone DP. Development of antibodies against p53 in lung cancer patients appears to be dependent on the type of p53 mutation. Cancer Res 1992; 52: 4168-74.

41 Lubin $R$, Schlichtholz B, Bengoufa D, Zalcman G Tredaniel J, Hirsch A, et al. Analysis of p53 antibodies in patients with various cancers define B-Cell epitopes of human p53 - distribution on primary structure and exposure on protein surface. Cancer Res 1993; 53: 5872-6.

42 Schlichtholz B, Trédaniel J, Lubin R, Zalcman G, Hirsch A, Soussi T. Analysis of p53 antibodies in sera of patient with lung carcinoma define immunodominant regions in the p53 protein. $B r f$ Cancer 1994; 69: 809-16. 